\title{
Evaluation of antimycobacterial activity of medicinal plants used by Malian traditional medicine practitioners to treat tuberculosis
}

\author{
Mahamadou BALLO ${ }^{1,2^{*}}$, Anou M. SOMBORO ${ }^{2}$, Mamoudou MAIGA ${ }^{2,3}$, \\ Bassirou DIARRA ${ }^{2}$, Moumine SANOGO $^{2}$, Adama DENOU ${ }^{1}$, Adiaratou TOGOLA ${ }^{1}$, \\ Estelle N. H. YOUL ${ }^{4}$, Sekou BAH ${ }^{5}$, Rokia SANOGO $^{1}$ and Drissa DIALLO ${ }^{1}$ \\ ${ }^{1}$ Department of Traditional Medicine- Faculty of Pharmacy, USTTB, Bamako, Mali. \\ ${ }^{2}$ University Clinical Research Center - SEREFO-Laboratory, USTTB, Bamako, Mali. \\ ${ }^{3}$ Center for Innovation in Global Health Technologies, Northwestern University, Chicago, USA. \\ ${ }^{4}$ Laboratoire de Pharmacologie, Université Joseph KI-ZERBO, Burkina Faso. \\ ${ }^{5}$ Service de Pharmacie Hospitalière du CHU du Point G et Faculté de Pharmacie/USTTB, Bamako, Mali. \\ "Corresponding author; E-mail: mballo87@gmail.com
}

\author{
Received: 09-08-2020 Accepted: 13-12-2020 Published: 31-12-2020
}

\begin{abstract}
Global Tuberculosis (TB) control is facing major challenges such as occurrence of multidrug-resistant (MDR) and extensively drug-resistant tuberculosis (XDR). The current TB drugs are getting less effective and associated with side effects limiting their use, especially with MDR and XDR infected patients. In Mali, many medicinal plants are used against various diseases including bacterial infections. The study aimed at studying the antimycobacterial activities of 60 extracts from 22 Malian medicinal. The antibacterial activity against Mycobacterium tuberculosis $\mathrm{H} 37 \mathrm{Rv}$ was assessed employing micro-broth dilution method. Out of 60 extracts evaluated, eleven from nine different plants were found to be active against H37Rv strain. The minimal inhibitory concentrations (MICs) ranked from $125 \mu \mathrm{g} / \mathrm{mL}$ to $1250 \mu \mathrm{g} / \mathrm{mL}$. The most active extracts $(125 \mu \mathrm{g} / \mathrm{mL})$ were represented by ethanolic extract of Saba senegalensis and Vitellaria paradoxa leaves, dichloromethane extract of Cola cordifolia leaves, Strychnos spinosa and Ximenia Americana roots. Ethanolic extract of Zizyphus mauritiana, Guiera senegalensis and methanolic extract of Anthocleista djalonensis also prevented the growth of H37Rv at $250 \mu \mathrm{g} / \mathrm{mL}$. The results suggest that Saba senegalensis, Vitellaria paradoxa, Cola cordifolia, Strychnos spinosa and Ximenia Americana could be potential sources of antimycobacterial molecules (C) 2020 International Formulae Group. All rights reserved.
\end{abstract}

Keywords: Medicinal plants, Mycobacterium tuberculosis H37Rv, Mali.

\section{INTRODUCTION}

Tuberculosis (TB) is one of the deadliest infectious diseases in the world. There were an estimated 10.4 million new cases of TB, resulting in approximately 1.7 million deaths, and $95 \%$ of these deaths occurring in developing countries (WHO,
2016). In Mali the estimated incidence rates of TB were 58 for 100,000 populations with 5809 new cases reported (Togo et al., 2017) The global TB control is facing major challenges, particularly with the phenomenon of TB/HIV coinfection and the increasing rate of multidrug-resistant (MDR) and extensively 
drug-resistant (XDR) TB. The current available first-line drugs are hence getting less effective due to this upsurge of drug resistance and the second lines are associated with side effects, which limits their usage (Jnawali and Ryoo, 2013; Floyd et al., 2018). Years ago, the world health organization (WHO) declared that TB is a world urgency and launched several programs to fight the disease, including the search of new remedies and/or new antituberculosis agents (Harries et al., 2018). In spite of the existence of therapeutic regimens, obstacles still remain among others, undesirable effects and toxicities of antituberculosis molecules, tolerance and the increasing resistance of germs to antibiotics thus, leading to the ineffectiveness of these available drugs. Those situations underline the urgency of searching for novel and efficient therapeutic agents.

Most of modern medicines originated from primeval herbal traditions. For their properties of possessing therapeutic values, medicinal plants are employed as medications for human diseases since centuries (Petrovska, 2012; Bashige et al., 2020). Numerous plant products with antibacterial, antiprotozoal and antifungal activities were reported to be useful either for local and/or systemic infections (Arif et al., 2009; Pandey and Kumar, 2013; Donfack et al., 2014). The plant kingdom is an unlimited source of new molecules that can be employed directly as an active ingredient or can serve as a guide molecule for the development of new therapeutic agents. Moreover, plant extracts are considered as potential sources of new antituberculosis drugs (Anochie, 2017; Gupta et al., 2017; Anochie et al., 2018; Ngoufo et al., 2019). The search for new medicines from natural origin with anti-tuberculosis action is therefore an important axis of research.

In Mali, numerous plants are utilized for the treatment of various diseases including bacterial infections by traditional practitioners (Willcox et al., 2012; Sanogo, 2014). The investigation of these traditionally used medicinal plants, is the subject of many works at the department of traditional medicine of the national institute of research and public health (INRSP/DMT) in Mali, in order to improve the development of traditional medicines in the country.

Therefore, the study aimed at studying the phytochemistry and the inhibitory activity against Mycobacterium tuberculosis of 22 local plants used by the traditional healers to "cure" tuberculosis in Mali. We sought here to provide a rational basis for the evaluation of the plant extracts and the determination of their antimycobacterial activities.

\section{MATERIALS AND METHODS}

\section{Plant materials}

The plant materials consisted of root barks, leaves, gum and stem barks that were collected from 22 different plants in Mali (Table 1). The plants were then authenticated by a botanist at the department of traditional medicine of Mali and an herbarium sheet of each plant was made available at the same department with reference numbers. The collected plants were cleaned with water, air dried under shade and then milled into powder using an electric grinder (Resch grinder type SM 2000 OSI/1400 $\mu \mathrm{pm}$ ). The powders were weighed with precision analytical balance (type SARTORIUS), and stored in sterile containers with lids at room temperature $( \pm 25$ $\left.{ }^{\circ} \mathrm{C}\right)$ prior usage.

\section{Extraction of plant materials}

The extraction of each of the powdered plant materials were performed following the method described previously by Basri and Fan (2005) with few adjustments made. Briefly, maceration by dichloromethane (DCM), 70\% ethanol and water (except for the leaves of $D$. oliveri and S. senegalensis on which decoction were performed) methods were employed. Powdered Plant material ( $20 \mathrm{~g}$ ) was immerged in the corresponding solvents $(200 \mathrm{~mL})$ under shaking condition during 24 hours at room temperature. Afterward, the macerates obtained following filtration of the mixture using a compress, were then concentrated in Rotavapor (Büchi R-200). The aqueous and ethanol concentrated extracts obtained from the rotavapor process were frozen and then freeze- 
dried, while the concentrates obtained after maceration with DCM were air-dried under hood. All the lyophilized extracts were stored in tightly closed and sterile bottle for testing. The decoction method followed similar procedure; briefly plant powders $(20 \mathrm{~g})$ were boiled in distilled water $(200 \mathrm{~mL})$ for 15 minutes, filtered after cooling down, then concentrated using the rotavapor. The resulting concentrate was then freeze-dried, and the lyophilized product was stored until further use.

\section{Thin layer chromatography (TLC)}

TLC was carried out as described by Bamba et al. (2020) on aluminum plate with support of the silica gel $60 \mathrm{FG}_{254}$ Merck. The Butanol-Acetic Acid-Water (60-15-25) solvent system was used for the aqueous, methanolic and ethanolic extracts; Ether Petroleum-Ethyl Acetate (1-1) was used for DCM extracts and petroleum ether. Plates were observed at 254 and $366 \mathrm{~nm}$ UV light. Godin's reagent was used to reveal the components of the extracts.

\section{Mycobacterial strain inoculum preparation Mycobacterium tuberculosis $\mathrm{H} 37 \mathrm{Rv}$, an} American Type Culture Collection strain (ATCC 27294) was used to investigate the antimycobacterial activity of the plant extracts. H37Rv strain was first sub-cultured on solid media (Middlebrook ${ }^{\circledR} 7 \mathrm{H} 11$ agar) for 14 days, and pure colonies were then inoculated in sterile liquid medium (Middlebrook ${ }^{\circledR} 7 \mathrm{H} 9$ ) supplemented with glycerol, Tween 80 and OADC (mixture of Oleic acid, Albumin, Dextrose and Catalase). Inoculum was incubated in a shacking incubator at $37{ }^{\circ} \mathrm{C}$ with $5 \% \mathrm{CO}_{2}$ for 4 to 5 days before adjusting the turbidity of the suspension to 0.5 Mac Farland $\left(1.5 \times 10^{8} \mathrm{CFU} / \mathrm{ml}\right)$. The adjusted suspension served as inoculum to determine the inhibitory activity of the extracts (Molina-Salinas et al., 2006).

\section{Minimum inhibitory concentration determination by Microplate Alamar Blue Assay}

The antimycobacterial activity of the plant extracts was determined using the microplate Alamar Blue Assay (MABA) as previously described by O'Neill et al. (2014) and Molina-Salinas et al. (2006). Briefly, the experimental compounds (plant extracts) were dissolved in 5\% dimethyl sulfoxide (DMSO) and then sonicated for 30 minutes to ensure total solubility. Concentrations of $1 \mathrm{mg} / \mathrm{mL}$ and $5 \mathrm{mg} / \mathrm{mL}$ were used as working solutions. Dilutions of the test extracts and an approved anti-tuberculosis drug (isoniazid, used as standard control drug) were made with varying concentrations. Hundred microliters of each concentration of the plant extracts and the standard drug (isoniazid) were dispensed into the corresponding sterile 96 well microtiter plates with the exception of the wells used for growth control (contain microorganisms and culture media only) and negative control (containing only culture media). Mycobacterium tuberculosis $\mathrm{H} 37 \mathrm{Rv}$ inoculum was also added to the corresponding 96 wells plates with the exception of the wells used for negative control, final volume in each well were $200 \mu$ l.

Plates were covered and sealed with parafilm and incubated at $37{ }^{\circ} \mathrm{C}$ for 7 days. At Day 7, $32.5 \mu \mathrm{L}$ of Alamar blue dye was added to all the 96 wells plates then incubated for 16 to 19 hours at $37^{\circ} \mathrm{C}$ in dark. After $16-19$ hours, plates were read, and validation of the test was conditioned by oxidation-reduction reaction of Alamar blue dye and bacterial cells indicated by the control wells (growth control, media control, and standard drug control wells). For the tested samples, the blue color is synonymous to lack of bacterial growth and therefore indicating the anti-tuberculosis activity. A turn to pink means bacterial growth. The MIC was defined as the lowest concentration, which prevented a colour change from blue to pink. 
Table 1: Malian medicinal plant investigated in this study.

\begin{tabular}{|c|c|c|c|c|c|}
\hline $\mathbf{N}^{\circ}$ & Scientific name & Family & Local name (Bambara) & Plant part used & Reference number \\
\hline 1 & Daniella oliveri & FABACEAE & Sanan & Leaves & 0190 \\
\hline 2 & Saba senegalensis & APOCYNACEAE & Zaban & Leaves & 0082 \\
\hline 3 & Securidaca longepedunculata & POLYGALACEAE & Joro & Roots, Leaves & 2063 \\
\hline 4 & Manilkara multinewis & SAPOTACEAE & Koungosumon, koya & Roots & 2660 \\
\hline 5 & Vitellaria paradoxa & SAPOTACEAE & $\mathrm{Si}$ & Leaves & 2278 \\
\hline 6 & Entada africana & FABACEAE & Samanéré & Leaves, Stem bark & 2368 \\
\hline 7 & Ostryoderris stuhlmannii & FABACEAE & Muso sana & Leaves & 1085 \\
\hline 8 & Erythrina senegalensis & FABACEAE & N'teblin, n'timini & Roots & 2493 \\
\hline 9 & Guiera senegalensis & COMBRETACEAE & Kunjè, kunyè & Leaves & 2345 \\
\hline 10 & Pteleopsis suberosa & COMBRETACEAE & Tèrèni, ntèlènin & Roots & 2335 \\
\hline 11 & Zizyphus mauritiana & RHAMNACEAE & Ntomono & Roots & 2441 \\
\hline 12 & Ximenia americana & OLACACEAE & Ntonkè & Roots & 2389 \\
\hline 13 & Calotropis procera & APOCYNACEAE & Sukunaji Bara & Roots & 0730 \\
\hline 14 & Moringa oleifera & MORINGACEAE & Bassi yirini & Leaves & 1391 \\
\hline 15 & Strychnos spinosa & LOGANIACEAE & Kule-kule & Root bark & 0009 \\
\hline 16 & Anthocleista djalonensis & LOGANIACEAE & Samãtlo & Stem bark, Leaves & 2675 \\
\hline 17 & Heliotropium indicum & BORAGINACEAE & Nõsiku & Leaves & 2376 \\
\hline 18 & Boscia angustifolia & CAPPARACEAE & Berecé & Leaves & 2208 \\
\hline 19 & Opilia celtidifolia & OPILIACEAE & Korôgué & Leaves & 2477 \\
\hline 20 & Crossopteryx febrifuga & RUBIACEAE & Balembo & Stem & 2478 \\
\hline 21 & Cola cordifolia & STERCULIACEAE & N'taba nogo & Leaves, Stem bark & 2886 \\
\hline 22 & Khaya senegalensis & MELIACEAE & Jala & gum & 2257 \\
\hline
\end{tabular}




\section{RESULTS \\ Collection of plants}

All the 22 plants included in this study belonged to the phylum Spermaphytes, under the branch of Angiosperms, class Dicotyledonous. They comprise of 13 families (Table 1), where the Fabaceae family was the most represented with 4 species followed by the Apocynaceae, Sapotaceae, Combretaceae and Loganiaceae families with 2 species respectively. Local names have been assigned to each plant corresponding to the name used to designate the plant by the local population of the place of harvest. Plants are harvested on the basis of their traditional use. The leaves were the most harvested (13 plants) followed by root bark (8 plants), stem bark (4 plants) and gum in one plant. An herbarium of each plant was deposited at the Mali DMT and registered under a given reference number.

\section{Extraction efficiency}

Sixty crude extracts were assessed from the 22 plants ( 9 plants freshly collected, and 33 extracts from 13 other plants were already available at the department of traditional medicine (DMT), Bamako, Mali). Of the 33 extracts provided by DMT, 19 were organic macerations and 14 were aqueous extracts. Out of 19 organic macerations, 10 were ethanolic macerations, 5 were methanolic macerations and 3 were DCM and 1 was petroleum ether macerated. Out of 14 aqueous extracts, there were 11 decoctions, 2 infusions and 1 maceration.

Extraction efficiency had concerned only the 9 plants freshly collected. On each plant part, three different extraction methods were carried out. In general, the best yield was obtained with the ethanolic maceration with Ximenia americana (31.85\%) which translates the richness of the plant into polar compounds soluble in $70 \%$ ethanol and the lowest was obtained with the DCM maceration of Crossopteryx febrifuga $(0.25 \%)$ (Table 2$)$.

\section{Thin layer chromatography (TLC)}

TLC allowed characterizing the presence of flavonoids, terpene compounds and sterols. The flavonoids were characterized in the ethanolic extract of the leaves of Guiera senegalensis, Moringa oleifera, Securidaca longepedunculata and Daniella oliveri. The TLC of the low polar extracts showed only the presence of triterpenes. Triterpenes and sterols were characterized in the methanolic extract of leaves of Moringa oleifera and Opilia celtidifolia, as well as in the ethanolic extract of root bark of Calotropis procera and Strychnos spinosa. Triterpenes were revealed in all the extracts of $C$. cordifolia, $X$. americana, $V$. paradoxa as well as in the ethanolic and DCM extracts of S. senegalensis and $S$. spinosa.

For the fluorescences observed under UV $366 \mathrm{~nm}$ not revealed by the Godin. Blue fluorescences are observed with ethanolic extract of stem bark of $C$. febrifuga, root barks of $Z$. mauritiana, and yellow with root barks of P. suberosa, S. spinosa. Blue and yellow with ethanolic extracts of root bark of $E$. senegalensis, DCM of stem bark of $C$. cordifolia. Red fluorescences were also observed with ethanolic extracts of leaves of $D$. oliveri, S. senegalensis, $V$. paradoxa $S$. longepedunculata, and with methanolic extracts of leaves of $C$. cordifolia and $A$. djalonensis. These yellow, blue, pink fluorescences could be coumarins and the red ones could be anthraquinones.

\section{Antimycobacterial activity of the plant extracts}

The finding showed that 19 extracts from 14 plants inhibited the replication of H37Rv strain, where the MICs were ranking from $125 \mu \mathrm{g} / \mathrm{mL}$ to $1250 \mu \mathrm{g} / \mathrm{mL}$. The most promising MIC values $(125 \mu \mathrm{g} / \mathrm{ml})$ were obtained from the ethanolic extraction of $V$. paradoxa and S. senegalensis leaves (Table 4), the dichloromethane extract of $C$. cordifolia leaves, and of $S$. spinosa and X. Americana roots (Table 5). Ethanolic extract of $G$. senegalensis leaves, Z. mauritiana root and methanolic extract of $A$. djalonensis leaves demonstrated a mycobacterial activity of MIC $=250 \mu \mathrm{g} / \mathrm{mL}$. 
Methanolic and dichloromethane extracts of Cola cordifolia stem barks was also be observed to be active at concentration of $312.5 \mu \mathrm{g} / \mathrm{mL}, 156.2 \mu \mathrm{g} / \mathrm{mL}$ respectively. Leaves of $O$. celtidifolia Extracted by Dichloromethane was active with a minimal concentration of $625 \mu \mathrm{g} / \mathrm{mL}$. The highest MIC $(1250 \mu \mathrm{g} / \mathrm{mL})$ was observed with methanolic extract of $C$. cordifolia leaves and with seven aqueous extracts including aqueous infused of A. djalonensis and Heliotropium indicum leaves. In addition, decocted of $O$. stuhlmannii, $S$. senegalensis, $S$. longepedunculata leaves and Z. mauritiana root bark (Table 3).

None of the aqueous extract inhibited the growth of $M$. tuberculosis at concentrations below $1000 \mu \mathrm{g} / \mathrm{mL}$. At the concentration of $1250 \mu \mathrm{g} / \mathrm{mL}, 5$ extracts performed by decoction and 2 by infusion inhibited the growth of M. tuberculosis H37Rv (Table 3).

The methanolic macerate of the leaves of $A$. djalonensis and the stem bark of $C$. cordifolia were active against $M$. tuberculosis as well as the ethanolic macerate of the leaves of $G$. senegalensis and those of the roots of $Z$. mauritiana. The most active were the ethanolic macerate of the leaves of S. senegalensis and $V$. paradoxa. Among the polar extracts, the ethanolic extracts were the most active (Table 4).

Among the 12 non polar extracts, 5 extracts by DCM have shown activity against M. tuberculosis, the most active being the roots of Ximenia americana and Strychnos spinosa and the leaves of Cola cordifolia (Table 5).

Table 2: Extraction efficiency of plants freshly collected.

\begin{tabular}{lcc}
\hline Plants (Part used) & Extraction method & Extraction efficiency (\%) \\
\hline Calotropis procera & Aqueous macerate & 13.40 \\
(Root bark) & DCM macerate & 5.05 \\
& 70\% ethanolic macerate & 7.40 \\
\hline Crossopteryx febrifuga & Aqueous macerate & 12.95 \\
(Stem bark) & DCM macerate & 0.25 \\
& 70\% ethanolic macerate & 15.1 \\
\hline Daniellia oliveri & Aqueous decoction & 19.65 \\
(Leaves) & DCM macerate & 4.80 \\
& 70\% ethanolic macerate & 22.60 \\
Khaya senegalensis & Aqueous macerate & 17.75 \\
(Gum) & DCM macerate & 0.4 \\
& $70 \%$ ethanolic macerate & 1 \\
\hline \multirow{2}{*}{ Pteolopsis suberosa } & Aqueous macerate & 16.6 \\
(Root bark) & DCM macerate & 0.6 \\
\hline \multirow{2}{*}{ Saba senegalensis } & $70 \%$ ethanolic macerate & 19.2 \\
(Leaves) & Aqueous decoction & 17.55 \\
& DCM macerate & 4.5 \\
Strychnos spinosa & $70 \%$ ethanolic macerate & 17.7 \\
(Root bark) & Aqueous macerate & 19.95 \\
\hline Vitellaria paradoxa & DCM macerate & 1.55 \\
(Leaves) & $70 \%$ ethanolic macerate & 17.2 \\
\hline \multirow{2}{*}{ Ximenia americana } & Aqueous macerate & 10.7 \\
(Root bark) & DCM macerate & 6.7 \\
& $70 \%$ ethanolic macerate & 19 \\
\hline
\end{tabular}


Table 3: Antimycobacterial activity of aqueous extracts against $M$. tuberculosis.

\begin{tabular}{lccc}
\hline \multicolumn{1}{c}{ Scientific Name } & Part of plant used & Extraction method & MIC $\boldsymbol{\mu g} / \mathbf{m l}$ \\
\hline Daniella oliveri & Leaves & Decoction & NA \\
Saba senegalensis & Leaves & Aqueous decoction & 1250 \\
Calotropis procera & Root barks & Maceration & NA \\
Crossopteryx febrifuga & Root barks & Maceration & NA \\
Khaya senegalensis & Gums & Maceration & NA \\
Pteolopsis suberosa & Root barks & Maceration & NA \\
Strychnos spinosa & Root barks & Maceration & NA \\
Vitellaria paradoxa & Leaves & Maceration & NA \\
Ximenia americana & Root barks & Maceration & NA \\
Securidaca longepedunculata & Root barks & Decoction & NA \\
Securidaca longepedunculata & Leaves & Aqueous decoction & 1250 \\
Manilkara multinewis & Root barks & Decoction & NA \\
Entada africana & Leaves & Decoction & NA \\
Entada africana & Stem barks & Decoction & NA \\
Ostryoderris stuhlmannii & Leaves & Aqueous decoction & 1250 \\
Ostryoderris stuhlmannii & Leaves & Maceration & NA \\
Boscia angustifolia & Leaves & Maceration & NA \\
Guiera senegalensis & Leaves & Aqueous decoction & 1250 \\
Zizyphus mauritiana & Root barks & Aqueous decoction & 1250 \\
Moringa oleifera & Leaves & Decoction & NA \\
Anthocleista djalonensis & Stem barks & Decoction & NA \\
Anthocleista djalonensis & Leaves & Aqueous infusion & 1250 \\
Heliotropium indicum & Leaves & Aqueous infusion & 1250 \\
\hline & & &
\end{tabular}

NA: Not active.

Table 4: Antimycobacterial activity of methanolic and ethanolic extracts against M. tuberculosis.

\begin{tabular}{lccc}
\hline Scientific Name & Part of plant used & Extraction Method & MIC $(\boldsymbol{\mu g} / \mathbf{m l})$ \\
\hline Calotropis procera & Root barks & Ethanolic macerate & NA \\
Crossopteryx febrifuga & Root barks & Ethanolic macerate & NA \\
Daniella oliveri & Leaves & Ethanolic macerate & NA \\
Khaya senegalensis & Gums & Ethanolic macerate & NA \\
Pteolopsis suberosa & Root barks & Ethanolic macerate & NA \\
Saba senegalensis & Leaves & Ethanolic macerate & 125 \\
Strychnos spinosa & Root barks & Ethanolic macerate & NA \\
Vitellaria paradoxa & Leaves & Ethanolic macerate & 125 \\
Ximenia americana & Root barks & Ethanolic macerate & NA \\
Erythrina senegalensis & Root barks & Ethanolic macerate & NA \\
Securidaca & Root barks & Ethanolic macerate & NA \\
longepedunculata & & &
\end{tabular}




\begin{tabular}{lccc}
$\begin{array}{l}\text { Securidaca } \\
\text { longepedunculata }\end{array}$ & Leaves & Ethanolic macerate & NA \\
Zizyphus mauritiana & Root barks & Ethanolic macerate & 250 \\
Entada africana & Leaves & Ethanolic macerate & NA \\
Entada africana & Stem barks & Ethanolic macerate & NA \\
Ostryoderris stuhlmannii & Leaves & Ethanolic macerate & NA \\
Guiera senegalensis & Leaves & Ethanolic macerate & 250 \\
Moringa oleifera & Leaves & Ethanolic macerate & NA \\
Opilia celtidifolia & Leaves & Methanolic macerate & NA \\
Cola cordifolia & Leaves & Methanolic macerate & 1250 \\
Cola cordifolia & Stem barks & Methanolic macerate & 156.2 \\
Anthocleista djalonensis & Leaves & Ethanolic macerate & NA \\
Anthocleista djalonensis & Leaves & Methanolic macerate & 250 \\
\hline NA: Not active. & & &
\end{tabular}

Table 5: Antimycobacterial activity of dichloromethane (DCM) and ether extracts against $M$. tuberculosis.

\begin{tabular}{lccc}
\hline Scientific Name & Part of plant used & Extraction Method & MIC $(\boldsymbol{\mu g} / \mathbf{m l})$ \\
\hline Calotropis procera & Root barks & DCM macerate & NA \\
Daniella oliveri & Leaves & DCM macerate & NA \\
Khaya senegalensis & Gums & DCM macerate & NA \\
Pteleopsis suberosa & Root barks & DCM macerate & NA \\
Saba senegalensis & Leaves & DCM macerate & NA \\
Strychnos spinosa & Root barks & DCM macerate & 125 \\
Vitellaria paradoxa & Leaves & DCM macerate & NA \\
Ximenia americana & Root barks & DCM macerate & 125 \\
Opilia celtidifolia & Leaves & DCM macerate & 625 \\
Cola cordifolia & Leaves & DCM macerate & 125 \\
Cola cordifolia & Stem barks & DCM macerate & 156.2 \\
Anthocleista djalonensis & Leaves & Ether macerate & NA \\
Isoniazide & - & - & 0.04 \\
\hline NA Non a & & &
\end{tabular}

NA: Not active.

\section{DISCUSSION}

According to previous studies, polyphenolics, flavonoids, sterols and triterpenoids have some antibacterial properties (Macabeo et al., 2012; Haidara et al., 2020). Plants in this study are sources of these substances and, we examined different crude plants extracts used in Mali by traditional practitioners to treat respiratory infections including tuberculosis.

The antimicrobial activities of crude plant extracts are classified into tree different categories based on their MIC values as follow: significant when the MIC value is less than 100 $\mu \mathrm{g} / \mathrm{mL}$, moderate (MIC value comprising in between 100-625 $\mu \mathrm{g} / \mathrm{mL}$ ) and low when the MIC is greater than $625 \mu \mathrm{g} / \mathrm{mL}$ (Simoes et al., 2009; Kuete et al., 2010). In our current study, the extracts were tested against Mycobacterium tuberculosis H37Rv strain (ATCC 27294).

In total, 60 extracts from 22 plants were tested, among them 11 extracts from 9 plants inhibited the growth of the Mycobacterium tuberculosis strain with MICs ranging from 125 to $625 \mu \mathrm{g} / \mathrm{mL}$. Hence, their inhibitory activity on mycobacterial growth was 
considered moderate. Dichloromethane extract of $O$. celtidifolia leaves was the least active with an MIC of $625 \mu \mathrm{g} / \mathrm{mL}$, which corresponds to the upper limit of the moderately active extracts. Methanolic extract of Cola cordifolia stem bark exhibited a MIC of $312.5 \mu \mathrm{g} / \mathrm{mL}$, as well as that of dichloromethane extract with a MIC of $156.2 \mu \mathrm{g} / \mathrm{ml}$. Ethanolic extract of Guiera senegalensis leaves, Zizyphus mauritiana root bark and methanolic extract of A. djalonensis leaves inhibited the growth of H37Rv strain with MIC of $250 \mu \mathrm{g} / \mathrm{mL}$. Study completed by Esimone et al. (2009) showed that the inhibitory activity of methanolic extract of leaves and root of Anthocleista djalonensis from against Mycobacterium smegmatis, a non-pathogenic strain, was 125 $\mu \mathrm{g} / \mathrm{mL}$.

In our study, the lowest inhibitory concentration $(125 \mu \mathrm{g} / \mathrm{mL})$ was observed with ethanolic extract of $S$. senegalensis, and $V$. paradoxa leaves, the same was observed with dichloromethane extract of $C$. cordifolia leaves and S. spinosa, X. Americana root barks. Antimycobacterial activity of these extracts could be explained by the presence of polyphenolic substances, flavonoids, sterols or terpene compounds. According to many researchers, these types of compounds may possess antimycobacterial properties. Kuete et al. (2011) showed the inhibitory activity of phenolic compounds (1,7-dihydroxyxanthone, morelloflavone and 7'-O-glucoside of morelloflavone) on M. tuberculosis. Besides, Macabeo et al. (2012), showed the inhibitory activity of the chloroformic extract of Uvaria rufa, stating that the phytochemical screening showed the presence of terpenoids, sterols and phenolic compounds. The antimycobacterial activity of extracts from these plants had not yet been reported by others.

These preliminary results are encouraging for further deep investigation of active principles on these plants that are active against $M$. tuberculosis.

This also justifies why traditional healers have been using these plants for years. However, it is important to determine the real value of these products in order to utilize them in regular modern medicine with optimal dose and formulation, which not only provide more options to patients but also prevent drug resistance.

\section{Conclusion}

This experimental study carried out at the Mali Department of Traditional Medicine and the HIV/TB research and training center Mycobacteriology laboratory (SEREFO), revealed the chemical compositions as well as the biological activities of plant extracts used by Malian traditional healers for TB treatment. This in vitro study showed that Malian plant extracts have antimycobacterial activities, allowing the inventory of plants with potential sources of new antimycobacterial molecules. These results could explain the use of these extracts by traditional healers in the treatment of tuberculosis in Mali. The isolation of flavonoids, sterols and triterpenes could open the door for new research avenues on these active plant extracts.

\section{COMPETING INTERESTS}

The authors declare that they have no competing interests

\section{AUTHORS' CONTRIBUTIONS}

MB: did the lab work, analyzed the data and commented the results, contributed to the drafting of the manuscript. AMS: contributed to the drafting of the protocol and the manuscript. BD and MS: carried out technical support for bacteriological tests and verified the accuracy of the results. AD and AT: carried out the technical follow-up of the phytochemical tests and provided certain extracts. MM, ENHY, SB and RS: participated in the correction of the manuscript. DD: was the principal investigator. All authors approved the final version of the manuscript

\section{ACKNOWLEDGEMENTS}

The authors acknowledge the team of the HIV/TB research and training center (CEREFO) Laboratory, University of Sciences, Techniques and Technologies of Bamako, Mali and the department of traditional 
medicine, Bamako, Mali for supporting this study.

\section{REFERENCES}

Anochie PI. 2017. Natural Products from African Medicinal Plants for Antituberculosis Therapy. Asian J. BioMedical Res., 3(4): 1-5. http://pmindexing.com/journals/index.ph $\mathrm{p} / \mathrm{AJBR}$

Anochie PI, Ndingkokhar B, Bueno J, Anyiam FE, Ossai-Chidi LN. 2018. African Medicinal Plants that Can Control or Cure Tuberculosis. Int. J. Pharm. Sci. Dev. Res., 4: 1-8. $\quad$ DOI : http://doi.org/10.17352/ijpsdr.000016

Arif T, Bhosale JD, Kumar N, Mandal TK, Bendre RS, Lavekar GS, Dabur R. 2009. Natural products-antifungal agents derived from plants. J. Asian Nat. Prod. Res., 11(9): 621-638. DOI: https://doi.org/10.1080/10286020902942 350

Bamba M, Neut C, Bordage S, Dramane S, N'guessan JK, Yacouba S, Samaillie J, Tah AZB, Fezan HTB, Sahpaz S. 2020. Screening phytochimique des extraits méthanoliques des feuilles de Combretum collinum et des racines de Anogeisus leiocarpus et effet antibactérien in vitro sur des souches de Staphylococcus aureus multirésistantes. Int. J. Biol. Chem. Sci., 14(6): 2362-2372. DOI: 10.4314/ijbcs.v14i6.34

Basri DF, Fan SH. 2005. The potential of aqueous and acetone extracts of galls of Quercus infectoria as antibacterial agents. Indian J. Pharmacol., 37(1): 26-29. DOI : 10.4103/0253-7613.13851.

Bashige VC, Bakari AS, Okusa PN, Kalonda EM, Lumbu JBS. 2020. Criblage phytochimique et activité antimicrobienne de six rhizomes comestibles utilisés en médecine traditionnelle à Lubumbashi (RDC). Int. J. Biol. Chem. Sci., 14(4): 1367-1380. DOI: $10.4314 /$ ijbcs.v14i4.16

Donfack VFD, Roque S, Trigo G, Fokou PVT, Tchokouaha LRY, Tsabang N, Zollo
PHA, Correia-neves M, Boyom FF. 2014 Antimycobacterial activity of selected medicinal plants extracts from Cameroon. Int. J. Biol. Chem. Sci., 8(1): 273-288. DOI: 10.4314/ijbcs.v8i1.24

Esimone CO, Nworu CS, Onuigbo EB, Omeje JU, Nsirim KL, Ogbu JC, Maria I. Ngwu MI, Chah KF. 2009. Anti-mycobacterial activity of root and leaf extracts of Anthocleista djalonensis (Loganiaceae) and Diospyros mespiliformis (Ebenaceae). Int. J. Green Pharm., 3(3): 201-205. DOI: 10.4103/09738258.56274

Floyd K, Glaziou P, Zumla A, Raviglione M. 2018. The global tuberculosis epidemic and progress in care, prevention, and research: an overview in year 3 of the End TB era. Lancet Respir. Med., 6(4): 299$314 . \quad$ DOI: $10.1016 /$ S22132600(18)30057-2

Gupta VK, Kumar MM, Bisht D, Kaushik A. 2017. Plants in our combating strategies against Mycobacterium tuberculosis: progress made and obstacles met. Pharm. Biol., 55(1): 1536-1544. DOI: https://doi.org/10.1080/13880209.2017.1 309440

Harries AD, Lin Y, Kumar AM V, Satyanarayana S, Takarinda KC, Dlodlo RA, Zachariah R, Olliaro PL. 2018. What can National TB Control Programmes in low-and middle-income countries do to end tuberculosis by 2030. F1000Research, $7 . \quad$ DOI: 10.12688/f1000research.14821.1

Haidara M, Diarra ML, Doumbia S, Denou A, Dembele D, Diarra B, Sanogo R. 2020. Plantes médicinales de l'Afrique de l'Ouest pour la prise en charge des affections respiratoires pouvant se manifester au cours de la Covid-19. Int. J. Biol. Chem. Sci., 14(8): 2941-2950. DOI: https://dx.doi.org/10.4314/ijbcs.v14i8.22

Jnawali HN, Ryoo S. 2013. First-and secondline drugs and drug resistance. In Tuberculosis: Current Issues in Diagnosis and Management. Mahboub B, Vats $M\left(1^{\text {st }}\right.$ ed $)$. IntechOpen Limited: 
London- United Kingdom; 163-180. DOI: http://dx.doi.org/10.5772/54960

Kuete V, Ngameni B, Mbaveng AT, Ngadjui B, Meyer JJM, Lall N. 2010. Evaluation of flavonoids from Dorstenia barteri for their antimycobacterial, antigonorrheal and anti-reverse transcriptase activities. Acta. Trop., 116(1): 100-104. DOI: https://doi.org/10.1016/j.actatropica.201 0.06 .005

Kuete V, Azebaze AGB, Mbaveng A, Nguemfo EL, Tshikalange ET, Chalard P, Nkengfack AE. 2011. Antioxidant, antitumor and antimicrobial activities of the crude extract and compounds of the root bark of Allanblackia floribunda. Pharm. Biol., 49(1): 57-65. DOI: https://doi.org/10.3109/13880209.2010.4 94673

Macabeo APG, Tudla FA, Krohn K, Franzblau SG. 2012. Antitubercular activity of the semi-polar extractives of Uvaria rufa. Asian Pac. J. Trop. Med., 5(10): 777-780. DOI: https://doi.org/10.1016/S19957645(12)60142-4

Molina-Salinas GM, Ramos-Guerra MC, Vargas-Villarreal J, Mata-Cárdenas BD, Becerril-Montes P, Said-Fernández S. 2006. Bactericidal activity of organic extracts from Flourensia cernua DC against strains of Mycobacterium tuberculosis. Arch. Med. Res., 37(1): 4549.

DOI:

https://doi.org/10.1016/j.arcmed.2005.04 .010

Ngoufo FN, Teke GN, Amslem CHE A, Kamga HLF. 2019. In vitro efficacy of five commercially available herbal preparations used in the treatment of typhoid fever in Bamenda Municipality, Cameroon. Int. J. Biol. Chem. Sci., 13(7): 3193-3201. DOI: 10.4314/ijbcs.v13i7.18

WHO. 2018. Global tuberculosis report. WHO, France.

https://apps.who.int/iris/bitstream/handle /10665/274453/9789241565646-eng.pdf

O'Neill TE, Li H, Colquhoun CD, Johnson JA, Webster D, Gray CA. 2014. Optimisation of the Microplate Resazurin Assay for Screening and Bioassay-guided Fractionation of Phytochemical Extracts against Mycobacterium tuberculosis. Phytochem. Anal., 25(5): 461-467. DOI : https://doi.org/10.1002/pca.2516

Pandey AK, Kumar S. 2013. Perspective on plant products as antimicrobial agents: A review. Pharmacologia., 4(7): 469-480. DOI:

10.5567/pharmacologia.2013.469.480

Petrovska BB. 2012. Historical review of medicinal plants' usage. Pharmacogn. Rev., 6(11): 1-5. DOI: 10.4103/09737847.95849

Sanogo R. 2014. Development of Phytodrugs from Indigenous Plants: The Mali Experience. In Novel Plant Bioresources: Applications in Food, Medicine and Cosmetics, Gurib-Fakim A $\left(1^{\text {st }}\right.$ edn). Wiley-Blackwell: Oxford-UK; 191-203.

DOI: 10.1002/9781118460566.ch15

Simoes M, Bennett RN, Rosa EAS. 2009. Understanding antimicrobial activities of phytochemicals against multidrug resistant bacteria and biofilms. Nat. Prod. Rep., 26(6): 746-57. DOI: https://doi.org/10.1039/B821648G

Togo ACG, Kodio O, Diarra B, Sanogo M, Coulibaly G, Bane S, Diallo F, Somboro AM, Cisse AB, Baya B, Goita D, Diabaté S, Koné B, Sarro YDS, Maiga M, Toloba Y, Belson M, Orsega S, Dao S, Murphy RL, Siddiqui S, Doumbia S, Diallo S. 2017. The most frequent Mycobacterium tuberculosis complex families in Mali (2006-2016) based on spoligotyping. Int. J. Mycobacteriology, 6(4): 379-386. DOI:

https://www.ijmyco.org/text.asp?2017/6/ 4/379/218627

Willcox M, Sanogo R, Diakite C, Giani S, Paulsen BS, Diallo D. 2012. Improved traditional medicines in Mali. J. Altern. Complement. Med., 18(3): 212-20. https://www.researchgate.net/publication 1221964863. 